\title{
Replacement of soybean meal with treated castor bean meal in supplements for grazing lambs
}

\author{
Substituição de farelo de soja por farelo de mamona em suplementos para borregos em \\ pastejo
}

\author{
FREITAS, Tiago Brandão ${ }^{1 *}$; FELIX, Tara ${ }^{2}$; PEDREIRA, Márcio dos Santos ${ }^{1}$; SILVA, \\ Robério Rodrigues $^{1}$; SILVA, Fabiano Ferreira da ${ }^{1}$; SILVA, Herymá Giovane de Oliveira ${ }^{1}$; \\ TIGRE, Jéssica Santos ${ }^{1}$
}

\footnotetext{
${ }^{1}$ Universidade Estadual do Sudoeste da Bahia, Departamento de Zootecnia, Itapetinga, Bahia, Brasil.

${ }^{2}$ Pennsylvania State University, Department of Animal Science, Park, United States of America.

*Endereço para correspondência: tibrandao@hotmail.com
}

\section{SUMMARY}

The objectives of this trial were to evaluate intake and nutrient digestibility, weight gain, and carcass characteristics of grazing lambs supplemented with increasing dietary inclusion of castor bean meal (CBM). Thirty-six Santa Inês-crossed, noncastrated, $120 \pm 15 \mathrm{~d}$ old lambs (initial $\mathrm{BW}=21.8$ $\pm 3.4 \mathrm{~kg}$ ) were randomly allotted to 1 of 4 dietary treatments. The treatments consisted of 4 levels of soybean meal substitution with lime treated CBM $(0,33,67$, and $100 \%)$ on the DM basis. The experimental design was a completely randomized design with 4 treatments and 9 replicates (lambs) for each treatment. Supplementation level was $1.6 \% \mathrm{BW}$ per animal/d. There was a linear decrease $(\mathrm{P}<0.01)$ for total DM intake and a quadratic effect (negative; $\mathrm{P}=0.05$ ) for pasture intake as $\mathrm{CBM}$ was increased in the supplement. There was a negative quadratic effect of CBM inclusion on NDFap intake, both in $\mathrm{g} / \mathrm{d}(\mathrm{P}=0.01)$ and as in $\mathrm{BW} \%(\mathrm{P}=$ 0.05 ). There was a linear effect (negative; $\mathrm{P}<0.01$ ) on DM and NDFap digestibility coefficients. There were no effects $(\mathrm{P} \geq 0.48)$ of treatments on $\mathrm{HCW}$, dressing percentage, carcass conformation, back fat or carcass length. Despite some negative effects on intake and nutrient digestibility, increasing CBM inclusion in the supplement, up to the substitution of all the soybean meal in the supplement, did not affect weight gain of grazing lambs or carcass characteristics.
Keywords: carcass characteristics, growth performance, Ricinus communis, sheep, supplementation

\section{RESUMO}

Os objetivos com este estudo foram avaliar a ingestão e a digestibilidade dos nutrientes, o ganho de peso e as características de carcaça de cordeiros em pastagem suplementados com níveis de farelo de mamona (FM) em substituição ao farelo de soja na dieta. Trinta e seis cordeiros (com $120 \pm 15$ dias de idade) cruzados da raça Santa Inês, nãocastrados, com peso corporal (PC) inicial de 21,8 \pm $3,4 \mathrm{~kg}$, foram separados de maneira que os grupos tivessem o mesmo PC médio e distribuídos aleatoriamente em 1 de 4 tratamentos dietéticos. Os tratamentos consistiram em 4 níveis de substituição $(0,33,67$ e $100 \%)$ de farelo de soja por FM, com base na matéria seca (MS). O delineamento experimental foi inteiramente casualizado com 4 tratamentos e 9 repetições (cordeiros) para cada tratamento. O nível de suplementação foi de 1,6\% PC por animal/dia. Houve uma diminuição linear $(\mathrm{P}<0,01)$ na ingestão total de MS e um efeito quadrático (negativo; $\mathrm{P}=0,05$ ) para a ingestão de pastagem à medida que o FM foi aumentado no suplemento. Houve um efeito quadrático negativo do aumento de FM do suplemento no consumo de FDNcp, tanto em $\mathrm{g} / \mathrm{d}(P=0,01)$ como em $\% \mathrm{PC}(\mathrm{P}=$ 
0,05). Houve efeito linear (negativo; $\mathrm{P}<0,01$ ) sobre os coeficientes de digestibilidade de MS e FDNcp. Não houve efeito $(\mathrm{P} \geq 0,48)$ de tratamento sobre peso de carcaça quente, rendimento de carcaça, conformação da carcaça, gordura de cobertura ou comprimento da carcaça. Apesar de alguns efeitos negativos sobre a ingestão e a digestibilidade de nutrientes, o aumento da inclusão de FM no suplemento, até a substituição de toda a farinha de soja no suplemento, não afetou o ganho de peso de cordeiros de pastagem ou características de carcaça.

Palavras-chave: características de carcaça, desempenho de crescimento, ovinos, Ricinus communis, suplementação

\section{INTRODUCTION}

Sheep production in Brazil is predominantly pasture-based and is characterized by seasonality of forage production throughout the year. During the dry season, forage availability and nutritional quality decreases. As expected, animal growth follows the seasonal availability of forage, weight gain is reduced during the dry season, and, often, carcass quality of sheep grazing in the dry season is also reduced (ABOUHEIF et al., 2013). Therefore, during the dry season in Brazil, it becomes necessary to supplement animals on pasture to improve growth performance. The aim of supplementation programs during the dry season is to provide nutrients, in quantity and quality, necessary to match the productive indexes of modern and competitive sheep industry in the tropics.

The replacement of "traditional" ingredients, such as corn and soybeans, with lower-cost ingredients that do not harm animal performance is one alternative to enhance profitability and production on these poor quality pastures. One such alternative feed source are byproducts of the biodiesel agribusiness. Among these products is castor bean meal (CBM; Ricinus communis). As a feed source, CBM contains 5 to $2 \%$ moisture, 21 to $40 \% \mathrm{CP}, 0.1$ to $1.7 \% \mathrm{EE}, 38$ to 47 $\% \mathrm{NDF}$, and 30 to $35 \% \mathrm{ADF}$, depending on variables such as previous treatment, level of dehulling and deoiling (AKANDE et al., 2015; DINIZ et al., 2010).

Production of castor beans is greatly increasing in Brazil. In 2014, approximately 128,000 ha of castor plants were planted (IBGE, 2015). Castor bean meal may be an economically viable alternative in ruminant feeding systems. The current literature related to CBM for ruminants has mainly targeted nutritional value and production performance for feedlot cattle and sheep (DINIZ et al., 2010; MENEZES et al., 2016; POMPEU et al., 2012), and there is little information about the effects of its use in supplements for grazing ruminants, especially growing sheep. Thus, it is necessary to establish of the optimum inclusion of CBM in supplements for grazing lambs.

Our hypothesis was that CBM in the supplement would effectively replace soybean meal without affecting intake, digestibility, weight gain, and carcass characteristics of grazing lambs.

The objectives were to evaluate the intake and nutrient digestibility, weight gain, and carcass characteristics of grazing lambs supplemented levels of increasing dietary inclusion of CBM.

\section{MATERIALS AND METHODS}

All animal procedures were approved by the Universidade Estadual do Sudoeste da Bahia (UESB) Ethics Committee on the 
Use of Animals - CEUA/UESB under protocol number $61 / 2014$.

The experiment was conducted at the Sheep and Goat Sector of the Animal and Rural Technology Department (DTRA) at UESB in Itapetinga city - Bahia, from June to September of 2013. The latitude and longitude of Itapetinga are $15^{\circ} 15^{\prime}$ South and $40^{\circ} 15^{\prime}$ West, respectively, and it is situated at $280 \mathrm{~m}$ altitude. The climate, according to Köppen classification, is a "Cw" mesothermal humid and warm sub-humid with dry winter. The total annual rainfall is 867 $\mathrm{mm}$ on average. Precipitation and monthly average temperatures during the trial period, as well as during the month that preceded it, are shown in Table 1 in order to better display the influence of climate variables on the pasture environment.

Table 1. Weather data recorded from May to September 2013 in Itapetinga - BA

\begin{tabular}{lccccc}
\hline \multirow{2}{*}{ Item } & \multicolumn{5}{c}{ Months } \\
\cline { 2 - 6 } & May/13 & Jun/13 & Jul/13 & Aug/13 & Sep/13 \\
\hline Temp. maximum average, ${ }^{\circ} \mathrm{C}$ & 28.3 & 26.4 & 26.5 & 26.2 & 27.2 \\
Temp. minimum average, ${ }^{\circ} \mathrm{C}$ & 19.6 & 19.2 & 17.9 & 17.6 & 18.8 \\
Temp. Absolute Maximum, ${ }^{\circ} \mathrm{C}$ & 31.0 & 29.0 & 29.0 & 30.0 & 31.0 \\
Temp. Absolute Minimum, ${ }^{\circ} \mathrm{C}$ & 16.0 & 15.0 & 15.0 & 12.0 & 17.0 \\
Relative humidity, $\%$ & 75.0 & 82.8 & 77.8 & 74.8 & 73.2 \\
\hline Rainfall, mm & 26.0 & 76.0 & 21.0 & 69.0 & 31.0 \\
\hline
\end{tabular}

${ }^{1}$ INMET, National Institute of Meteorology. Website: www.inmet.gov.br

Thirty-six Santa Inês-crossed, noncastrated, $120 \pm 15 \mathrm{~d}$ old lambs (initial BW $=21.8 \pm 3.4 \mathrm{~kg}$ ) were used in this trial. The experimental area used was $5,640 \mathrm{~m}^{2}$ and was divided into 4 paddocks, all provided with drinking and feed troughs with $20 \mathrm{~cm}$ of linear bunk space per head to allow the feeding of all animals simultaneously. Prior to the initiation of the trial, animals had a $14 \mathrm{~d}$ adaptation period to incrementally transition intakes of the supplements. From day 14 to day 8, they were all fed $0.8 \%$ BW per head of the $0 \%$ treatment diet (with no CBM), and from day 7 to day 0 , they were fed $1.6 \%$ BW of the $0 \%$ treatment and kept on pasture. During this period, the lambs were dewormed with Cydectin $^{\circledR}$ (Moxidectin $1 \%$; Fort Dodge Animal Health, Fort Dodge, IA), vaccinated (5mL subcutaneous, Poli-Star ${ }^{\circledR}$; Vallée S.A., São Paulo, SP, Brazil) for clostridial diseases and identified with individual ear tags.

After the adaptation period, all 36 animals were randomly allotted to 1 of 4 dietary treatments. The treatments consisted of 4 levels of soybean meal (SBM) substitution with lime treated $\mathrm{CBM}(0,33,67$, and 100 $\%$ ) on the DM basis. The experimental design was a complete random design with 4 treatments and 9 replicates (lambs) for each treatment. There were 9 lambs per pasture and 1 treatment in each pasture at a time. The remainder of the supplements were wheat bran, corn, urea, and mineral salt (Table 3). Lambs grazed on pasture that was predominantly braquiarão grass (Urochloa brizantha cv. Marandu) and Tifton 85 (Cynodon dactylon). Pasture characteristics during the experimental 
period are shown in Table 2. The supplements were made according to the nutritional recommendations of NRC (2007), to target an ADG of $200 \mathrm{~g}$, with 20 $\%$ CP. The level of supplementation was $1.6 \% \mathrm{BW}$ per animal/d, coming from the supplement in the trough, which was provided daily at $1000 \mathrm{~h}$. The experiment duration was $84 \mathrm{~d}$. The lambs rotated paddocks every 7 days, at random, through all 4 paddocks, in order to reduce the effect of forage biomass from each paddock.

Table 2. Pasture characteristics during the experimental periods

\begin{tabular}{lcccc}
\hline \multirow{2}{*}{ Item } & \multicolumn{3}{c}{ Period } & \multirow{2}{*}{ Average } \\
\cline { 2 - 3 } & Jun/Jul & Jul/Aug & Aug/Sep & \\
\hline Forage mass, kg/ha & 1680 & 1250 & 1114 & 1348 \\
DMpd $^{1}$ availability, kg/ha & 1074 & 673 & 550 & 765 \\
Forage availability, kg DM/ $100 \mathrm{~kg} \mathrm{BW} \mathrm{d}^{-1}$ & 4.0 & 2.7 & 2.3 & 3.0 \\
Forage height, cm & 22.0 & 18.0 & 16.0 & 18.7 \\
Leaves, \% & 22.3 & 20.0 & 16.7 & 19.7 \\
Culms, \% & 46.0 & 40.3 & 45.6 & 44.0 \\
Dead matter, \% & 31.7 & 39.7 & 37.6 & 36.3 \\
Leaf : steam ratio & 0.49 & 0.50 & 0.37 & 0.45 \\
\hline${ }^{1} \mathrm{DMpd}=$ potentially digestible dry matter. DMpd $=0.98 *(100-\mathrm{NDF})+(\mathrm{NDF}-\mathrm{iNDF})$. &
\end{tabular}

In order to detoxify the CBM, a calcium hydroxide (lime; $\mathrm{Ca}(\mathrm{OH})_{2}$ ) solution was applied. Each $\mathrm{kg}$ of the alkaline agent was diluted in 10 liters of water and homogenized to make a solution. Then, the solution was applied to CBM in accordance to a ratio of 60 grams of lime per $\mathrm{kg}$ of CBM, as is, as recommended by Oliveira et al. (2007). After mixing CBM with lime solution, the material was allowed to stand for $12 \mathrm{~h}$, and then dry at room temperature for a period between 48 and $72 \mathrm{~h}$, depending on climate conditions.

The forage mass ( $\mathrm{kg}$ of DM per ha) estimate was performed on $28 \mathrm{~d}$ intervals. Five samples were taken per paddock at soil level with a square of $0.25 \mathrm{~m}^{2}$ according to methodology described by McMeniman (1997). At the time of collection, sample division was carried out in 2 sub-samples per paddock: one was weighed and taken immediately to the oven with forced air circulation at 55 ${ }^{\circ} \mathrm{C}$ for 72 hours for further determination of the chemical analysis (DM, NDF and iNDF); and the other was used to determine the structural components of the pasture. Destructive sampling, where manual separation of harvested forage in to leaves (leaf blades), culms (stems + sheaths), and dead material, was used to determine the structural components of the pasture. The proportions of components in samples were calculated as the percentage of the total weight after they dried for $72 \mathrm{~h}$ in an oven with forced ventilation at $55{ }^{\circ} \mathrm{C}$. The potentially digestible dry matter (DMpd) was estimated according to the equation: 


$$
\mathrm{DMpd}=0.98 \times(100-\mathrm{NDF})+(\mathrm{NDF}-\mathrm{iNDF})
$$

where: $\mathrm{NDF}=$ neutral detergent insoluble fiber; and $\mathrm{iNDF}=$ indigestible NDF.

Forage height was also measured at the beginning of each period, at 10 random points in each paddock, using a graduated ruler measuring from the bottom to the canopy of the pasture.

Forage collection for chemical composition analysis was performed according to Sollenberger \& Cherney (1995), by grazing simulation. Approximately $300 \mathrm{~g}$ of fresh forage per paddock was collected manually in the beginning of each period.

Forage and supplement ingredients were analyzed for DM, total nitrogen (TN), ether extract (EE), ash (OM was calculated by difference), neutral detergent fiber (NDF) and acid detergent fiber (ADF), neutral detergent insoluble nitrogen (NDIN), acid detergent insoluble nitrogen

$$
\mathrm{NFC}=100-[(\mathrm{CP}-\mathrm{CPu}+\mathrm{U})+\mathrm{EE}+\mathrm{ash}+\mathrm{NDFap}]
$$

where: $\mathrm{CPu}=\mathrm{CP}$ content from urea $(\%)$; and $\mathrm{U}=$ urea content $(\%)$.

For indigestible dry matter (iDM), indigestible neutral detergent fiber (iNDF) and indigestible acid detergent fiber (iADF), dietary samples were incubated for 288 hours in the rumen of 2 Holstein-Zebu-crossbred cows $(\mathrm{H} \times \mathrm{Z})$ for later determinations of $\mathrm{iDM}$ content, iNDF and $\mathrm{iADF}$, following procedures described by Detmann et al. (2012).
(ADIN), and lignin as methods described in AOAC (2000). The neutral detergent fiber corrected for ash and protein (NDFap) was estimated according to Hall (2003). Feces were analyzed for DM, TN, EE, ash, and NDFap. The percentage of total carbohydrates in feed and feces were obtained from the equation:

$$
\mathrm{TC}=100-(\% \mathrm{CP}+\% \mathrm{EE}+\% \mathrm{ash})
$$

according Sniffen et al. (1992), and nonfibrous carbohydrate (NFC) in forage, using the equation: NFC $=100-\%$ NDFap - \%CP - \%EE - \%ash, according to Hall (2000). Urea was used as a source of nonprotein nitrogen compound. Thus, dietary levels of NFC in supplements were estimated by adjusting Hall proposition (2000):
Carbohydrate fractions were estimated according to Sniffen et al. (1992) and Hall (2003), as cited above. Total digestible nutrients (TDN) was calculated as the sum of digestible crude protein (DCP), digestible neutral detergent fiber corrected for ash and protein (DNDFap), digestible non-fibrous carbohydrates corrected for ash and protein (DNFCap), and digestible ether extract (DEE) multiplied by 2.25 , according to Weiss (1999):

$$
\mathrm{TDN}=\mathrm{DCP}+\mathrm{DNDFap}+\mathrm{DNFCap}+\mathrm{DEE} \times 2.25
$$

Estimation of feed intake for grazing animals is a challenge under experimental conditions. However, research has showed results that validate the estimation of herbage and supplement intake with the aid of external and internal markers (HELLWING et al., 2015; SALIBA et al., 2015; SMIT et al., 2005; UNDI et al., 2008). 
To estimate fecal production, Enriched and Purified Isolated Lignin from Eucalyptus grandis (LIPE ${ }^{\mathbb{B}}$; UFMG, Minas Gerais, Brazil) was used as external marker (SALIBA et al., 2015). A $250 \mathrm{mg}$ capsule containing LIPE $^{\circledR}$ was orally administered for each animal for 6 consecutive days (d 7 to $\mathrm{d} 12$ of period 2 ); the first $2 \mathrm{~d}$ were to stabilize the fecal excretion of the marker. Fecal samples were collected directly from the rectum twice a day at $0800 \mathrm{~h}$ and $1500 \mathrm{~h}$ for 5 consecutive days (from d 9 to $d 13$ of period 2) and stored in a cold chamber at $-10{ }^{\circ} \mathrm{C}$. After that, the fecal samples were dried, ground and composed. Approximately $10 \mathrm{~g}$ of each composed sample of feces was sent to the Federal University of Minas Gerais (UFMG) to estimate the total daily fecal output (SALIBA et al., 2015).

To determine the dry matter intake of the supplement (SI), titanium dioxide has been used as an external marker, according to the equation:

$$
\mathrm{SI}=(\mathrm{FP} * \mathrm{CTF}) / \mathrm{CTS}
$$

where SI is the dry matter intake of the supplement $(\mathrm{g} / \mathrm{d})$; FP is the daily fecal production $(\mathrm{g} / \mathrm{d})$; CTF is the concentration of titanium dioxide $\left(\mathrm{TiO}_{2}\right)$ in feces $(\mathrm{g} / \mathrm{g}$ $\mathrm{DM}$ ) and CTS is the concentration of titanium dioxide in the supplement $(\mathrm{g} / \mathrm{g}$ DM).

Five grams of $\mathrm{TiO}_{2}$ for each $495 \mathrm{~g}$ of supplement $(1 \%$ concentration $)$ were mixed. This mixture was offered to the animals for $12 \mathrm{~d}$ (a $7 \mathrm{~d}$ adaptation period to obtain a more homogeneous excretion plateau, and for 5 days of fecal collection). The adaptation period was from $\mathrm{d} 2$ to $\mathrm{d} 8$ of period 2. The 5 days of fecal collection were the same for fecal production estimation (from d 9 to $\mathrm{d} 13$ of period 2).
The fecal $\mathrm{TiO}_{2}$ content was determined according to Myers et al. (2004).

Total apparent digestibility and dry matter intake (DMI) was estimated from fecal production, verified with the aid of LIPE as external marker and iNDF as internal marker. Dry matter intake was obtained by the following equation:

$$
\mathrm{DMI}=\{[(\mathrm{FP} * \mathrm{IMF})-\mathrm{IMS}] / \mathrm{IMF}\}+\mathrm{SI}
$$

where DMI $=$ dry matter intake $(\mathrm{kg} / \mathrm{d}) ; \mathrm{FP}$ $=$ fecal production $(\mathrm{kg} / \mathrm{d}) ; \quad \mathrm{IMF}=$ concentration of the internal marker (iNDF) in feces $(\mathrm{kg} / \mathrm{kg})$; IMS = iNDF intake from supplement $(\mathrm{kg} / \mathrm{d})$; IMF $=$ concentration of iNDF present in forage $(\mathrm{kg} / \mathrm{kg})$; and SI is the supplement intake (DM basis; $\mathrm{kg} / \mathrm{d}$ ).

Animals were weighed at the beginning and end of the trial, after fasting for about 16 hours to determine initial BW (IBW), final $\mathrm{BW}(\mathrm{FBW}), \mathrm{ADG}$, and feed efficiency (G:F). Intermediate weight measurements were taken every 28 days to assess the ADG to adjust the supplement supply. Feed efficiency was determined by dividing the weight gain $(\mathrm{kg})$ by the amount of feed intake $(\mathrm{kg})$ during the experimental period. Before slaughter, body condition score (BCS) was estimated while the animals were standing on flat surface, by palpation of the transverse processes of the lumbar and dorsal vertebrae and sternum of animals. Scores were assigned to be within a range of 1 to 5 , with intermediate values of 0.5 . Score 1 was for lean animals and score 5 for obese animals (RUSSELL et al., 1969).

At the end of the experiment, the animals were slaughtered at the Goats and Sheep Experimental Unit (UECO) slaughterhouse at the university (UESB). After evisceration, carcasses were weighed to 
obtain the hot carcass weight (HCW) and, soon after, were sent to cold storage at $4^{\circ} \mathrm{C}$, where they remained for a period of $24 \mathrm{~h}$, hanging by the metatarsal joint. After cooling, back fat, carcass length, and conformation were measured. The carcass length was measured from the front edge of the pubic bone to the cranial edge of the first rib; the back fat (BF) was taken on the external surface of the Longissimus dorsi muscle between the 12 th and 13 th ribs, using a caliper. To evaluate the conformation of the carcass, the scores were set as follows: Concave $=1$; Sub rectilinear $=2$; Rectilinear $=3$; Sub convex $=4 ;$ and Convex $=5$. The subjective evaluation was adapted from the EUROP system assessment lamb carcasses (EUROPEAN COMMUNITY, 1992). The calculation of the dressing percentage was made as follows:

$$
\text { Dressing } \%=\mathrm{HCW} / \mathrm{FBW} \times 100 \text {. }
$$

The design was completely randomized with 4 treatments in the model:

$$
\mathrm{Y}_{\mathrm{ij}}=\mu+\operatorname{Tr}_{\mathrm{i}}+\mathrm{e}_{\mathrm{ij}}
$$

where $\mathrm{Y}_{\mathrm{ij}}=$ observed value for the characteristic analyzed; $\mu=$ general average; $\operatorname{Tr}_{\mathrm{i}}=$ effect of diet; $\mathrm{e}_{\mathrm{ij}}=$ experimental error. Data were evaluated by analysis of variance and polynomial regression using the MIXED procedure of SAS statistical software (version 9.2, SAS Inst. Inc., Cary, NC). For all variables, the animal was considered the experimental unit, despite of the lack of pasture replication, because the efforts made to measure individual traits with external markers. Orthogonal contrasts were used to detect the linear and quadratic effects of the increase in levels of CBM replacing soybean meal in supplements. The level of probability of
0.05 was adopted for the type I error. Trends are discussed at $0.05<\mathrm{P}<0.10$.

\section{RESULTS AND DISCUSSION}

In the current trial, there was a decrease (linear; $\mathrm{P}<0.01)$ in DMI (g/day) by lambs on different treatments as the proportion of the CBM in the supplement was increased. Increasing $\mathrm{CBM}$ in the supplement resulted in a $19.2 \%$ total DMI decrease when compared treatment $100 \%$ CBM substitution to $0 \% \quad \mathrm{CBM}$ substitution. This decrease in consumption $(\mathrm{g} / \mathrm{d})$ can be explained by the lignin and NDF rise in supplement (Table 3) as CBM is increased. Pasture intake $(\mathrm{g} / \mathrm{d})$ was responsible for the difference in total DMI $(\mathrm{g} / \mathrm{d})$, because the supplement intake was kept at the $1.6 \%$ BW level for all treatments. The decrease trend in pasture intake (BW \%) among treatments means a $28.6 \%$ decrease when $\mathrm{CBM}$ was increased from treatment $0 \%$ to $100 \%$. This numerical difference can become important as it would allow more animals on the same area, and it could be used as a strategy for increasing gain per area.

There was a negative effect (quadratic; $\mathrm{P}$ $=0.05)$ of $\mathrm{CBM}$ inclusion in the supplement on pasture intake $(\mathrm{g} / \mathrm{d})$. There was a decrease trend $(\mathrm{P}=0.07)$ in pasture intake (BW \%) among treatments. However, there was no effect $(\mathrm{P} \geq 0.10)$ of treatment on DMI (BW \%), which was $2.44 \%$ on average. As there was no daily supplement remains in the bunks in any of the treatments, the response on the DMI (BW \%) followed a similar behavior to that presented in pasture intake (BW $\%)$. In a study of confined lambs, Pompeu et al. (2012) observed DMI values of 
$969.2,880.0,866.5$, and $829.4 \mathrm{~g} / \mathrm{d}$ to levels of $0,33,67$ and $100 \%$ when CBM replaced soybean meal in the diet, respectively. Although these intakes are greater than those of the present trial, it should be considered that confined animals usually have less environmental challenges, such as endo and ecto parasites infestation, exposure to great temperature variations, or need to walk for food, what would inherently favor the increase in DMI by confined animals (psychogenic regulation of consumption; Mertens (1994; 1996).

Table 3. Composition of supplements fed to lambs and grazed forage, on a dry matter basis

\begin{tabular}{|c|c|c|c|c|c|}
\hline \multirow{2}{*}{ Item } & \multicolumn{4}{|c|}{ Substitution Level $^{\top}$} & \multirow{2}{*}{ Forage } \\
\hline & $0 \%$ & $33 \%$ & $67 \%$ & $100 \%$ & \\
\hline Ground corn & 46.8 & 50.6 & 58.0 & 65.6 & - \\
\hline Wheat bran & 28.0 & 24.0 & 16.0 & 8.0 & - \\
\hline Soybean meal & 20.0 & 13.4 & 6.6 & 0.0 & - \\
\hline Castor bean meal ${ }^{2}$ & 0.0 & 6.6 & 13.4 & 20.0 & - \\
\hline Urea & 1.2 & 1.4 & 2.0 & 2.4 & - \\
\hline Mineral mixture $^{3}$ & 4.0 & 4.0 & 4.0 & 4.0 & - \\
\hline \multicolumn{6}{|l|}{ Analyzed composition, $\%$} \\
\hline Organic matter ${ }^{4}$ & 91.20 & 90.59 & 90.07 & 88.85 & 90.12 \\
\hline Crude protein & 18.89 & 18.25 & 18.33 & 17.96 & 11.70 \\
\hline NDIP, $\% \mathrm{CP}^{5}$ & 30.98 & 33.08 & 36.55 & 39.56 & 40.18 \\
\hline ADIP, $\% \mathrm{CP}^{6}$ & 23.99 & 26.63 & 31.06 & 35.02 & 35.96 \\
\hline Ether Extract & 3.32 & 3.02 & 2.44 & 1.69 & 1.67 \\
\hline Total Carbohydrates ${ }^{7}$ & 68.99 & 69.32 & 69.30 & 69.20 & 76.75 \\
\hline Non-fiber carbohydrates ${ }^{8}$ & 39.18 & 40.37 & 40.59 & 39.60 & 17.54 \\
\hline NDF & 38.75 & 38.21 & 39.43 & 41.83 & 72.31 \\
\hline NDFap $^{9}$ & 31.98 & 31.48 & 32.33 & 33.94 & 59.21 \\
\hline $\mathrm{ADF}$ & 16.53 & 18.60 & 19.16 & 23.94 & 30.27 \\
\hline Lignin & 3.37 & 5.36 & 6.84 & 10.23 & 5.90 \\
\hline $\mathrm{iNDF}^{10}$ & 8.07 & 10.39 & 12.25 & 14.75 & 24.20 \\
\hline
\end{tabular}

${ }^{1}$ Percent replacement castor bean meal by soybean meal in the supplement composition.

${ }^{2}$ Castor bean meal was treated with $\mathrm{Ca}(\mathrm{OH})_{2}$ at a rate of $60 \mathrm{~g} \mathrm{Ca}(\mathrm{OH})_{2} / \mathrm{kg}$ of $\mathrm{CBM}$ (as-is). Chemical composition: DM, 87.72\%; CP, 25.69\%; NDIP, 42.50\%; ADIP, 39.48\%; EE, 0.04\%; NDF, 64.39\%; NDFap, 42.19\%; ADF, 51.06\%; Lignin, 26.11\%; Ash, 22.47\%, iNDF, 36.08\%.

${ }^{3}$ Mineral mixture per kilogram of product contained: $150 \mathrm{~g} \mathrm{Ca}$ as $\mathrm{CaCO}_{3}, 65 \mathrm{~g} \mathrm{P}$ as $\mathrm{CaHPO}_{4}, 107 \mathrm{~g} \mathrm{Na}$ as $\mathrm{NaCl}, 12 \mathrm{~g} \mathrm{~S}$ as $\mathrm{S}_{8}, 6,000 \mathrm{mg} \mathrm{Mg}$ as $\mathrm{MgO}$ and $\mathrm{MgSO}_{4}, 175 \mathrm{mg} \mathrm{Co}$ as $\mathrm{CoSO}_{4}, 100 \mathrm{mg} \mathrm{Cu}$ as CuSO $4,175 \mathrm{mg}$ $\mathrm{I}$ as $\mathrm{Ca}\left(\mathrm{IO}_{3}\right)_{2}, 1,440 \mathrm{mg} \mathrm{Mn}$ as $\mathrm{MnSO}_{4}, 27 \mathrm{mg} \mathrm{Se}$ as $\mathrm{Na}_{2} \mathrm{SeO}_{3}, 6,000 \mathrm{mg} \mathrm{Zn}$ as $\mathrm{ZnSO}_{4}$.

${ }^{4} \mathrm{OM}=100-\mathrm{Ash}$

${ }^{5} \mathrm{NDIP}=$ neutral detergent insoluble protein, as percentage of $\mathrm{CP}$;

${ }^{6} \mathrm{ADIP}=$ acid detergent insoluble protein, as percentage of $\mathrm{CP}$

${ }^{7} \mathrm{TC}=100-(\% \mathrm{CP}+\% \mathrm{EE}+\% \mathrm{ash})$

${ }^{8}$ For supplement: $\mathrm{NFC}=100-[(\mathrm{CP}-\mathrm{CPu}+\mathrm{U})+\mathrm{EE}+\mathrm{ash}+\mathrm{NDFap}]$; where: $\mathrm{CPu}=\mathrm{CP}$ content from urea $(\%)$; and $\mathrm{U}=$ urea content $(\%)$;

For forage: NFC $=100$ - \%NDFap - \%CP - \%EE - \%ash.

${ }^{9} \mathrm{NDFap}=$ neutral detergent fiber corrected for ash and protein.

${ }^{10} \mathrm{iNDF}=$ indigestible neutral detergent fiber. Samples were incubated for 288 hours. 
There was a negative linear effect of the inclusion of castor meal in the diets on $\mathrm{CP}$ $(\mathrm{P}=0.01)$, EE $(\mathrm{P}<0.01)$, and TDN $(\mathrm{P}<$ 0.01 ) intake (Table 3$)$. Despite the decrease in CP intake, the content of this nutritional component in the diet remained constant, very close to $16 \%$ for all treatments, demonstrating that animals, despite differences in total DMI (g/d) among treatments, selected forage in a similar manner, with the same quality. Non-fiber carbohydrates intake did not differ $(\mathrm{P}=$ 0.15 ) among treatments, averaging 193.5 g/d. Non-fiber carbohydrates intake was similar among treatments, which can be explained by the maintenance of supplement intake at similar levels among treatments, since NFC in supplements was twice as much as the NFC in forage. Thus, forage intake $(\mathrm{g} / \mathrm{d})$ decrease was not sufficient to elicit a NFC intake decrease.

There was a negative effect (linear; $\mathrm{P}<$ 0.01 ) of treatment on DM and NDFap digestibility (Table 4). The negative effect of treatment on DM and NDFap digestibility was expected because there was a gradual increase in iNDF and lignin concentrations in supplements as CBM was increased (Table 3). In agreement, Diniz et al. (2010) found a reduction in ruminal degradation of DM when beef cattle were fed increasing calcium oxide treated CBM in the supplement. In grazing production systems, NDF digestibility is a very important parameter for overall efficiency.

Table 4. Daily nutrient intake, and DM and NDFap apparent total tract digestibility in grazing lambs supplemented with increasing levels of castor bean meal

\begin{tabular}{|c|c|c|c|c|c|c|c|}
\hline \multirow{2}{*}{ Item } & \multicolumn{4}{|c|}{ Substitution Level $^{\top}$} & \multirow{2}{*}{ SEM } & \multicolumn{2}{|c|}{$P$-value } \\
\hline & $0 \%$ & $33 \%$ & $67 \%$ & $100 \%$ & & Linear & Quadratic \\
\hline Dry matter intake, $\mathrm{g} / \mathrm{d}$ & 687.9 & 595.6 & 567.9 & 555.9 & 15.47 & $<0.01$ & 0.14 \\
\hline Dry matter intake, BW \% & 2.73 & 2.31 & 2.40 & 2.32 & 0.078 & 0.10 & 0.27 \\
\hline Pasture intake, $\mathrm{g} / \mathrm{d}$ & 281.7 & 198.2 & 178.0 & 194.5 & 13.60 & 0.01 & 0.05 \\
\hline Pasture intake, BW \% & 1.12 & 0.75 & 0.77 & 0.80 & 0.059 & 0.07 & 0.07 \\
\hline NDFap intake, $g / d^{2}$ & 296.7 & 235.9 & 231.4 & 229.8 & 6.99 & $<0.01$ & 0.01 \\
\hline NDFap intake, BW \% & 1.18 & 0.91 & 0.98 & 0.95 & 0.034 & 0.03 & 0.05 \\
\hline Crude protein intake, $\mathrm{g} / \mathrm{d}$ & 109.7 & 97.2 & 92.3 & 89.6 & 2.98 & 0.01 & 0.39 \\
\hline Ether Extract intake, g/d & 18.2 & 15.6 & 12.5 & 9.4 & 0.69 & $<0.01$ & 0.76 \\
\hline NFC intake, $g / d^{3}$ & 207.1 & 198.7 & 187.1 & 181.3 & 6.59 & 0.15 & 0.92 \\
\hline TDN intake, $\mathrm{g} / \mathrm{d}^{4}$ & 437.5 & 351.3 & 335.8 & 310.0 & 14.80 & $<0.01$ & 0.25 \\
\hline \multicolumn{8}{|l|}{ Digestibility, $\%$} \\
\hline Dry matter & 63.10 & 57.26 & 57.53 & 54.26 & 1.02 & $<0.01$ & 0.48 \\
\hline NDFap $^{2}$ & 53.46 & 44.49 & 40.54 & 39.71 & 1.50 & $<0.01$ & 0.11 \\
\hline
\end{tabular}

${ }^{1}$ Percentage of soybean meal replaced by castor bean meal in supplements.

${ }^{2} \mathrm{NDF} a \mathrm{p}=$ neutral detergent fiber corrected for ash and protein.

${ }^{3} \mathrm{NFC}=$ non-fiber carbohydrate.

${ }^{4} \mathrm{TDN}=$ total digestible nutrients.

Any negative effect on NDF digestibility can also compromise DM digestibility, animal performance, and efficiency of the entire production system. This could also explain the decrease in total DMI in the current experiment. Another factor that may have contributed to a lower DM digestibility is the greater ADIP fraction 
content in CBM (approximately $40 \%$ of CP; Table 4). Thus, as CBM concentration was increased in the diet, CP digestibility was decreased because $\mathrm{CP}$ content in diets was kept very close. Similar to this work, Barros et al. (2011) observed a linear decrease in DM and NDFap digestibility when grazing heifers were supplemented with CBM levels replacing soybean meal, 59 to $63 \%$ for DM, and 64 to $68 \%$ for NDFap digestibility.

There was no effect $(\mathrm{P} \geq 0.15)$ of replacing soybean meal by $\mathrm{CBM}$ in supplements for grazing lambs on final BW, ADG, or BCS (Table 5). Final BW was not influenced $(\mathrm{P} \geq 0.64)$ by treatments, averaging $29.2 \mathrm{~kg}$, due to the similarity of ADG $(\mathrm{P} \geq 0.41)$, which averaged $85.9 \mathrm{~g} / \mathrm{d}$ for all treatments. In contrast to these results, Pompeu et al. (2012) observed an ADG decrease (197, 160,155 and $130 \mathrm{~g} / \mathrm{d}$ ) in feedlot lambs fed the same levels $(0,33,67$ and $100 \%)$ of CBM replacing soybean meal, respectively. The ADG results on the current trial cannot be explained by decrease in DMI nor decrease in DM digestibility, as it also should have been affected by treatments. Our hypothesis is that the length of the current trial was not long enough to show differences in ADG. However, the results show that for short periods of supplementation, CBM can successfully replace soybean meal in the diet. Final BW was not influenced $(\mathrm{P} \geq$ 0.64 ) by treatments.

Table 5. Growth performance of grazing lambs supplemented with increasing levels of castor bean meal

\begin{tabular}{|c|c|c|c|c|c|c|c|}
\hline \multirow{2}{*}{ Item } & \multicolumn{4}{|c|}{ Substitution Level $^{1}$} & \multirow{2}{*}{ SEM } & \multicolumn{2}{|c|}{ P-value } \\
\hline & $0 \%$ & $33 \%$ & $67 \%$ & $100 \%$ & & Linear & Quadratic \\
\hline $\mathrm{n}^{2}$ & 9 & 9 & 8 & 8 & - & - & - \\
\hline Initial BW, kg & 22.19 & 22.39 & 21.50 & 21.55 & - & - & - \\
\hline Final BW, kg & 28.59 & 30.22 & 28.84 & 29.06 & 0.722 & 0.99 & 0.64 \\
\hline $\mathrm{ADG}, \mathrm{g} / \mathrm{d}$ & 76.12 & 93.27 & 87.34 & 87.04 & 5.057 & 0.57 & 0.41 \\
\hline Feed efficiency ${ }^{3}$ & 0.110 & 0.158 & 0.154 & 0.158 & 0.009 & 0.09 & 0.21 \\
\hline Initial $\mathrm{BCS}^{4}$ & 3.00 & 2.94 & 2.94 & 3.00 & 0.051 & 0.99 & 0.59 \\
\hline Final $\mathrm{BCS}^{4}$ & 3.33 & 3.38 & 3.16 & 3.16 & 0.064 & 0.20 & 0.83 \\
\hline BCS change & 0.33 & 0.44 & 0.22 & 0.16 & 0.058 & 0.15 & 0.46 \\
\hline
\end{tabular}

${ }^{\mathrm{T}}$ Percentage of soybean meal replaced by castor bean meal in supplements.

${ }^{2} \mathrm{n}=$ number of animals ( 1 animal from $67 \%$ and 1 animal from $100 \%$ treatments were removed for nontreatment related reasons).

${ }^{3}$ Feed efficiency $=$ ADG $/ \mathrm{DMI}$

${ }^{4} \mathrm{BCS}=$ body condition score. It varied from 1 to 5 . Score 1 was for lean animals and score 5 for obese animals.

There was no effect $(\mathrm{P} \geq 0.15)$ of treatment on final BCS or BCS change, 3.26 and 0.29 on average, respectively. The similar response on Final BCS and BCS change can be explained by the
ADG similarity among lambs throughout the trial period, in addition to genetic, age and body structure similarity of the animals. 
There was a positive trend (linear; $\mathrm{P} \geq$ 0.09 ) in feed efficiency among treatments as CBM was increased in the supplement. Menezes et al. (2016) observed no difference in feed efficiency when lambs were fed increasing CBM dietary concentrations. However, Pompeu et al. (2012) observed a decrease in feed efficiency as CBM was increased in the lambs' diets. The feed efficiency response on the current study is largely driven by the lower DMI at a similar ADG when CBM was increased in supplement, thus improving feed efficiency as CBM increased in grazing lambs' diets.

We had hypothesized that increasing CBM in the supplement to replace SBM would negatively impact carcass characteristics; however, this was not the case. There was no effect $(\mathrm{P} \geq 0.77)$ of treatments on $\mathrm{HCW}$, no effect $(\mathrm{P} \geq 0.52)$ of treatments on dressing \%, nor effect (P $\geq 0.68$ ) of treatment on BF (Table 6). Growth rate and final $\mathrm{BW}$, which did not differ in our trial, influence $\mathrm{HCW}$. Therefore, it was not surprising to find that there was also no effect of treatments on $\mathrm{HCW}$, with an average of $13.04 \mathrm{~kg}$. In the current study, lambs averaged $46.2 \%$ dress. In a 4 year study, with data from 436 lambs of different genotypes fed on pasture and access to grain crop paddocks, Álvarez et al. (2013) found dressing \% ranged between 44.0 and 47.2 $\%$ and $\mathrm{HCW}$ between 12.8 and $13.8 \mathrm{~kg}$, thus, the lambs in this trial were comparable to Brazil industry averages.

Table 6. Carcass characteristics of grazing lambs supplemented with increasing levels of castor bean meal

\begin{tabular}{|c|c|c|c|c|c|c|c|}
\hline \multirow{2}{*}{ Item } & \multicolumn{4}{|c|}{ Substitution Level ${ }^{1}$} & \multirow{2}{*}{ SEM } & \multicolumn{2}{|c|}{$P$-value ${ }^{2}$} \\
\hline & $0 \%$ & $33 \%$ & $67 \%$ & $100 \%$ & & Linear & Quadratic \\
\hline $\mathrm{n}^{3}$ & 7 & 8 & 7 & 7 & - & - & - \\
\hline HCW, kg & 13.08 & 13.33 & 12.91 & 12.83 & 0.406 & 0.77 & 0.85 \\
\hline Dressing $\%^{4}$ & 45.4 & 44.9 & 49.9 & 44.9 & 1.681 & 0.82 & 0.52 \\
\hline Conformation $^{5}$ & 2.7 & 2.4 & 2.4 & 2.5 & 0.096 & 0.50 & 0.48 \\
\hline $\begin{array}{l}\text { Degree of Fat } \\
\text { Cover }^{6}\end{array}$ & 1.9 & 2.1 & 1.8 & 1.7 & 0.121 & 0.50 & 0.50 \\
\hline Back fat, $\mathrm{mm}^{7}$ & 0.39 & 0.40 & 0.32 & 0.37 & 0.035 & 0.68 & 0.80 \\
\hline $\begin{array}{l}\text { Carcass length, } \\
\mathrm{cm}^{8}\end{array}$ & 50.4 & 51.5 & 50.0 & 49.7 & 0.543 & 0.48 & 0.55 \\
\hline
\end{tabular}

${ }^{\mathrm{I}}$ Percentage of soybean meal replaced by castor bean meal in supplements.

${ }^{2}$ Orthogonal polynomial contrasts for increasing castor bean meal inclusion in the diets.

${ }^{3} \mathrm{n}=$ number of animals (some animals were removed for non-treatment related reasons).

${ }^{4}$ Dressing percentage was calculated by dividing hot carcass weight by final body weight.

${ }^{5}$ Conformation was estimated as follows: Concave $=1$; Sub rectilinear $=2$; Rectilinear $=3$; Sub convex $=4$; and Convex $=5$

${ }^{6}$ For degree of fat cover: $1=$ lean, absence of fat up to $1 \mathrm{~mm}$ fat thickness; $2=$ little fat, 1 to $3 \mathrm{~mm}$ thickness; $3=$ mid fat, 3 to $6 \mathrm{~mm}$ thickness; 4 = fat uniform, 6 to $10 \mathrm{~mm}$ thickness; and $5=$ excessive fat, above $10 \mathrm{~mm}$ thickness.

${ }^{7}$ Back fat was measured between the $12^{\text {th }}$ and $13^{\text {th }}$ ribs.

${ }^{8}$ Carcass length was measured from the front edge of the pubic bone to the cranial edge of the first rib. 
It would be reasonable to expect $\mathrm{BF}$ to decrease with increasing CBM inclusion in the supplement because TDN intake decreased as CBM increased; however, this was not the case. This may be explained by the low BF in lamb carcasses in the current trial, $0.37 \mathrm{~mm}$ on average.

There was also no effect of treatment $(\mathrm{P} \geq$ 0.48 ) on carcass conformation, which was 2.5 on average. Carcass length was not affected $(\mathrm{P} \geq 0.48)$ by treatments, averaging $50.4 \mathrm{~cm}$, in the current trial. These can be explained as a result of similar animal growth, given the absence of difference in ADG and FBW.

The replacement of soybean meal by calcium hydroxide-treated CBM in the supplement for grazing lambs reduced DMI $(\mathrm{g} / \mathrm{d})$ as a consequence of decreased forage intake. Thus, there was a decrease in energy and protein intake. The replacement of SBM with CBM also decreased total DM and NDFap apparent digestibility. Despite some negative effects on intake and nutrient digestibility, increasing $\mathrm{CBM}$ in the supplement, up to the entire substitution of soybean meal, did not affect weight gain or carcass characteristics of grazing lambs supplemented for 84 days.

\section{REFERENCES}

ABOUHEIF, M.; AL-OWAIMER, A.; KRAIDEES, M.; METWALLY, H.; SHAFEY, T. Effect of restricted feeding and realimentation on feed performance and carcass characteristics of growing lambs. Revista Brasileira de Zootecnia, v.42, p.95-101, 2013.
AKANDE, T.O.; ODUNSI, A.A., AKINFALA, E.O. A review of nutritional and toxicological implications of castor bean (Ricinus communis L.) meal in animal feeding systems. Journal of Animal Physiology and Animal Nutrition, v.100, p.201-210, 2015. Doi: 10.1111/jpn. 12360.

ÁLVAREZ, J.M.; RODRÍGUEZ IGLESIAS, R.M.; GARCÍA VINENT, J.; GIORGETTI, H.; RODRÍGUEZ, G.; BASELGA, M. Introduction of sheep meat breeds in extensive systems: Lamb carcass characteristics. Small Ruminant

Research, v.109, p.9-14, 2013.

ANANDAN, S.; ANIL KUMAR, G.K.; GHOSH, J.; RAMACHANDRA, K.S. Effect of different physical and chemical treatments on detoxification of ricin in castor cake. Animal Feed Science and Technology, v.120, p.159-168, 2005.

ASSOCIATION OF OFFICIAL ANALYTICAL CHEMISTS - AOAC. Official methods of analysis. $17^{\text {th }} \mathrm{ed}$. Arlington, 2000.

BARROS, L.V.; PAULINO, M.F.; DETMANN, E.; VALADARES FILHO, S.C.; LOPES, S.A.; ROCHA, A.A.; VALENTE, E.E.L.; ALMEIDA, D.M. Replacement of soybean meal by treated castor meal in supplements for grazing heifer during the dry-rainy season period. Revista Brasileira de Zootecnia, v.40, p.843-851, 2011.

DETMANN, E.; SOUSA, M.A.; VALADARES FILHO, S.C.; QUEIROZ, A.C.; BERCHIELLI, T. T.; SALIBA, E.O.S.; CABRAL, L.S.; PINA, D.S.; LADEIRA, M.M.; AZEVEDO, J.A.G. Métodos para análise de alimentos. Rio Branco: Suprema, 2012. 214p. 
DINIZ, L.L.; VALADARES FILHO, S.C.; CAMPOS, J.M.S.; VALADARES, R.F.D.; SILVA, L.D.; MONNERAT, J.P.I.S.; BENEDETI, P.B.; OLIVEIRA, A.S.; PINA, D.S. Effects of castor meal on the growth performance and carcass characteristics of beef cattle. Asian Australasian Journal of Animal Sciences, v.23, p.1308-1318, 2010.

EUROPEAN COMMUNITY. Council Regulation (EEC) No 2137/92 of 23 July 1992. OJ L. 214, 1992. p.1-5.

HALL, M.B. Neutral detergent-soluble carbohydrates. Nutritional relevance and analysis. Gainesville: University of Florida, 2000.76p.

HALL, M.B. Challenges with nonfiber carbohydrate methods. Journal of Dairy Science, v.81, p.3226-3232, 2003.

HELLWING, A.L.F.; LUND, P.; WEISBJERG, M.R.; OUDSHOORN, F.W.; MUNKSGAARD, L.;

KRISTENSEN, T. Comparison of methods for estimating herbage intake in grazing dairy cows. Livestock Science, v.76, p.6174, 2015.

\section{IBGE. Dados de previsão de safra.}

Available on:

$<$ http://www.sidra.ibge.gov.br/bda/prevsaf/ >. Accessed on: 03 September 2015.

McMENIMAN, N.P. Methods of estimating intake of grazing animals. In: REUNIÃO ANUAL DA SOCIEDADE BRASILEIRA DE ZOOTECNIA, 34, 1997, Juiz de fora. Anais... Juiz de Fora: Sociedade Brasileira de Zootecnia, 1997. 131-168.
MENEZES, D.R.; COSTA, R.G.;

ARAÚJO, G.G.L.; PEREIRA, L.G.R.; MEDEIROS, G.R.; OLIVEIRA, J.S.; NASCIMENTO, T.V.C.; RODRIGUES, R.T.S.; PEREIRA FILHO, J.M.; BUSATO, K.C. Detoxified castor meal in substitution of soybean meal in sheep diet: growth performance, carcass characteristics and meat yield. Tropical Animal Health and Production, v.48, p.297-302, 2016.

MERTENS, D.R. Regulation of forage intake. In: FAHEY Jr, G.C. (Ed.). Forage Quality, Evaluation, and Utilization. Madison: American Society of Agronomy, 1994. p.450-493.

MERTENS, D.R. Using fiber and carbohydrate analyses to formulate dairy rations. Informational Conference with Dairy and Forages Industries. US Dairy Forage Research Center, 1996.

MYERS, W.D.; LUDDEN, P.A.; NAYIGIHUGU, V.; HESS, B.W. Technical Note: a procedure for the preparation and quantitative analysis of samples for titanium dioxide. Journal of Dairy Science, v.82, n.1, p.179-183, 2004.

NATIONAL RESEARCH COUNCIL NRC. Nutrient requirements of ruminants: Sheep, Goats, Cervids, and New World Camelids. Washington, DC: National Academies Press, 2007.

OLIVEIRA, A.S.; CAMPOS, J.M.S.; OLIVEIRA, M.R.C.; BRITO, A.F.; VALADARES FILHO, S.C.; DETMANN, E.; VALADARES, R.F.D.; SOUZA, S.M.; MACHADO, O.L.T. Nutrient digestibility, nitrogen metabolism and hepatic function of sheep fed diets containing solvent or expeller castorseed meal treated with calcium hydroxide. Animal Feed Science and Technology, v.158, p.15-28, 2010. 
OLIVEIRA, A.S.; OLIVEIRA, M.R.C.; CAMPOS, J.M.S. Eficácia de diferentes métodos de destoxificação da ricina do farelo de mamona. In: II CONGRESSO DA REDE BRASILEIRA DE

TECNOLOGIA DE BIODIESEL, 2., 2007, Brasília. Anais... Brasília: MCT/ABIPTI, 2007. 1-6.

POMPEU, R.C.F.F.; CÂNDIDO, M.J.D.; PEREIRA, E.S.; BOMFIM, M.A.D.; CARNEIRO, M.S.S.; ROGÉRIO, M.C.P.; SOMBRA, W.A.; LOPES, M.N. Desempenho produtivo e características de carcaça de ovinos em confinamento alimentados com rações contendo torta de mamona destoxificada em substituição ao farelo de soja. Revista Brasileira de Zootecnia, v.41, n.3, p.726-733, 2012.

RUSSEL, A.J.F.; DONEY, J.M.; GUNN, R.G. Subjective assessment of body fat in live sheep. Journal of Agricultural Science, v.72, n.3, p.451-454, 1969.

SALIBA, E.O.S.; FARIA, E.P.; RODRIGUEZ, N.M.; MOREIRA, G.R.; SAMPAIO, I.B.M.; SALIBA, J.S.; GONÇALVES, L.C.; BORGES, I.; BORGES, A.L.C.C. Use of Infrared Spectroscopy to Estimate Fecal Output with Marker LIPE ${ }^{\circ}$. International Journal of Food Sciences and Nutrition and Dietetics, v.4, p.1-10, 2015. doi:dx.doi.org/10.19070/2326-3350SI04001

SMIT, H.J.; TAWEEL, H.Z.; TAS, B.M.; TAMMINGA, S.; ELGERSMA, A. Comparison of techniques for estimating herbage intake of grazing dairy cows.

Journal of Dairy Science, v.88, p.18271836, 2005.
SNIFFEN, C.J.; O'CONNOR, J.D.; VAN SOEST, P.J.; FOX, D.G.; RUSSELL, J.B. A net carbohydrate and protein system for evaluating cattle diets: II. Carbohydrate and protein availability. Journal of Dairy Science, v.70, p.3562-3577, 1992.

SOLLENBERGER, L.E.; CHERNEY, D.J.R. Evaluating forage production and quality. In: BARNES, R.F.; MILLER, D.A.; NELSON, C.J. Forages: the science of grassland agriculture. $5^{\text {th }}$ ed. Ames: Iowa State Univ. Press, 1995. p.97-110.

UNDI, M.; WILSON, C.; OMINSKI, K.H.; WITTENBERG, K.M.. Comparison of techniques for estimation of forage dry matter intake by grazing beef cattle. Canadian Journal of Animal Science, v.88, p.693-701, 2008.

WEISS, W.P. Energy prediction equations for ruminant feeds. In: CORNELL NUTRITION CONFERENCE FEED MANUFACTURES, 61., 1999, Ithaca. Proceedings... Ithaca: Cornell University, 1999. p.176-185.

Data de recebimento: 14/02/2017

Data de aprovação: 12/07/2017 